\title{
Analiza wykorzystania systemu car-sharing i jednoosobowych samochodów elektrycznych w transporcie miejskim
}

http://dx.doi.org/10.18778/8142-085-3.16

Mateusz Olejniczak, Angelika Mendakiewicz

Katedra Logistyki i Transportu Przemysłowego, Wydział Transportu

Politechnika Śląska

\section{Wstęp}

Z roku na rok w Polsce i na świecie wzrasta liczby samochodów przypadających na jednego mieszkańca, co przekłada się na wzrost liczby samochodów na drodze. Problem jest najbardziej widoczny w centrach dużych miast, gdzie parkingi są przepełnione, a infrastruktura miejska nie jest w stanie poradzić sobie z rosnącą liczbą samochodów. Obecnie w celu zmniejszenia natężenia ruchu $\mathrm{w}$ miastach stosuje się metody i strategie mające zniechęcić mieszkańców do korzystania $\mathrm{z}$ transportu indywidualnego i nakłonić ich do korzystania $\mathrm{z}$ transportu miejskiego. Można to osiągnąć poprzez wprowadzenie wysokich opłat za parkowanie w mieście i zamykanie ulic dla transportu indywidualnego. Niestety, mimo że przejazd transportem publicznym jest tańszy i efektywniejszy na krótkich odcinkach, spora część społeczeństwa nadal wybiera samochód osobowy zamiast transportu publicznego. Rozwiązaniem dla tych osób może być system car-sharing.

Car-sharing to usługa mobilna umożliwiająca wspólne korzystanie z samochodu za pomocą aplikacji mobilnej car-sharing. W odróżnieniu od tradycyjnej wypożyczalni samochodów nie wymusza na użytkowniku zwrotu samochodu w miejscu jego pobrania. Usługa jest kierowana do osób korzystających z samochodu sporadycznie, które przejeżdżają rocznie mniej niż 10 tys. kilometrów, a także firm, które nie wykorzystują na co dzień swoich samochodów firmowych. Zjawisko car-sharingu jest spotykane głównie w miejscach o wysokim zaludnieniu. Usługa ma na celu redukowanie liczby samochodów w miastach poprzez efektywniejsze wykorzystanie środków transportu (Larish, 2014).

Uważa się, że wprowadzenie do flot transportowych firm car-sharingowych, jednoosobowych samochodów elektrycznych może jeszcze efektywniej zmniejszyć natężenie ruchu na drogach. Statystycznie w Polsce podczas jednej podróży jedzie 
samochodem 1,1 osoby, co oznacza, że przeważnie jeździmy sami. Wprowadzenie jednoosobowych samochodów elektrycznych może być zatem skutecznym rozwiązaniem tego problemu. W ostatnich latach wiele firm oferujących usługi car-sharingowe rozważa dodanie do swojej floty samochodów elektrycznych lub nawet całkowitą wymianę samochodów spalinowych na elektryczne (Larish, 2014).

Celem niniejszego artykułu jest analiza możliwości zastosowania systemu car-sharingu i jednoosobowych samochodów elektrycznych w transporcie miejskim oraz identyfikacja czynników wpływających na jego rozwój. W części teoretycznej niniejszej publikacji przedstawione zostaną samochody elektryczne wykorzystywane $\mathrm{w}$ transporcie indywidualnym, ze szczególnym uwzględnieniem stadiów rozwoju tej nowej technologii oraz wdrożonych projektów jednoosobowych samochodów marki Renault Twizzy. Następnie zweryfikowana zostanie hipoteza przeniesienia nowej technologii i systemu car-sharingu do transportu miejskiego.

W części badawczej niniejszego artykułu przeprowadzona zostanie analiza złożoności problemu wprowadzenia nowoczesnej technologii w logistyce miejskiej przy użyciu analizy SWOT. W tym celu wygenerowano trzydzieści sześć czynników zewnętrznych, które poddano analizie. Ocena pozwoliła wybrać po trzy kluczowe czynniki zewnętrzne mające wpływ na szanse i zagrożenia związane z rozwojem technologii car-sharingu. Jednocześnie uwzględniono dwadzieścia trzy czynniki wewnętrzne rozwoju technologii car-sharingu, a następnie w ten sam sposób dokonano ich oceny i wyboru czterech najważniejszych. Całość artykułu podsumowano wnioskami wynikającymi z opisanej części teoretycznej i badawczej.

\section{Samochody elektryczne wykorzystywane w transporcie indywidualnym}

Pojazdy z napędem elektrycznym zyskują coraz większą popularność w branży motoryzacyjnej. Obecnie większość czołowych producentów samochodów albo pracuje nad wprowadzeniem samochodów elektrycznych do swojej oferty, albo już to zrobiła. Póki co, na drogach przeważają pojazdy napędzane silnikami spalinowymi, w przyszłości powinno się to zmienić (Chłopek, Lasocki, 2014: 33-39).

Prędkośćsamochodów elektrycznych mieści się w przedziale 50-120km/h. Najszybsze potrafią osiągać nawet $200 \mathrm{~km} / \mathrm{h}$. Osiągana prędkość zależy od wielu czynników:

- masy pojazdu,

- jego kształtu,

- napięcia zasilania.

Najbardziej decydującym czynnikiem jest napięcie zasilania - im wyższe, tym pojazd może osiągać większe prędkości (Pawelski, Pawelski, Pałczyński, 2007: 19-24). 
Większość samochodów elektrycznych na jednym pełnym naładowaniu akumulatorów może przebyć trasę około 80 kilometrów. Nowe modele, z pojemniejszymi akumulatorami oraz wyższym napięciem, mogą zwiększyć tę trasę do 300 kilometrów. Ważne jest ładowanie pojazdu. Może trwać 3-10 godzin, jednak nie musi być pełne. Typowy pojazd posiada 12-24 akumulatorów, które generują napięcie rzędu 96-144 V. Ich trwałość wynosi 3 lata, po czym należy je wymienić. Koszt zestawu to około 1000 dolarów (Pawelski, Pawelski, Pałczyński, 2007).

Ważną cechą przemawiającą za samochodami elektrycznymi jest ich ekologiczność oraz zużycie paliwa. $Z$ przeprowadzonych testów wynika, iż praktycznie pojazdy te nie emitują zanieczyszczeń, $z$ wyjątkiem cząstek stałych powstałych w wyniku kontaktu kół z jezdnią czy wzniecania pyłów z jezdni. Charakteryzuje je również mniejsze natężenie hałasu niż w przypadku pojazdów z silnikami spalinowymi. Istnieje wiele możliwości zasilania samochodów elektrycznych. Są przeprowadzane badania nad ogniwami wodorowymi czy zasilaniem energią odnawialną (Chłopek, 2012).

\section{Jednoosobowy samochód elektryczny na przykładzie Renault Twizzy}

W 2012 r. koncern Renault pokazał światu swój nowy samochód - Renault Twizzy. Jest to pojazd w pełni napędzany energią elektryczną, wyposażony w jedno miejsce siedzące, z możliwością powiększenia go o miejsce dla pasażera za kierowcą lub wykorzystania przestrzeni jako dodatkowego miejsca na bagaż. Cechują go niewielkie wymiary, dzięki czemu świetnie sprawdza się w mieście. Posiada wbudowany akumulator litowo-jonowy o pojemności $6,1 \mathrm{kWh}$, zapewniający zasięg jazdy 60-80 kilometrów przy stosowaniu zasad ekonomicznej jazdy. Maksymalna prędkość wynosi około $80 \mathrm{~km} / \mathrm{h}$, co jest wystarczające w miejskich warunkach. Pełne ładowanie akumulatorów trwa 3,5 godziny za pomocą przewodu o długości 3 metrów, kompatybilnego z gniazdami domowymi o napięciu $230 \mathrm{~V}$. Marka Renault oferuje każdemu klientowi możliwość spersonalizowania pojazdu. W ofercie dostępne są zestawy naklejek, jak również elementy samego pojazdu. Cena samochodu, bez akumulatorów, $\mathrm{w}$ dniu premiery kształtowała się na poziomie $33900 \mathrm{zt}^{1}$.

Pojazd ten idealnie wpisuje się $\mathrm{w}$ idee car-sharingu dzięki swoim niewielkim wymiarom, możliwości ładowania z wielu dostępnych źródeł czy zasięgowi jazdy.

1 http://moto.pl/MotoPL/1,88389,14055475,Renault_Twizy_w_Polsce_Ceny_od_33_900_ zl.html [dostęp 06.04.2017]. 


\section{Car-sharing}

Car-sharing jest to system umożliwiający korzystanie z samochodu osobowego w obrębie miasta bez konieczności posiadania go na własność. System umożliwia wynajem pojazdu w dogodnej dla użytkownika lokalizacji i zwrot samochodu w dowolnym miejscu wybranym przez użytkownika. Czas użytkowania pojazdu jest ustalony na podstawie liczby opłaconych godzin. System dodatkowo umożliwia wynajęcie samochodu za pomocą urządzenia mobilnego, co pozwala na rezerwację samochodu za pośrednictwem Internetu. Odbiór samochodu jest samoobsługowy, ponieważ użytkownik ma możliwość otwarcia samochodu za pomocą smartfona lub specjalnej karty car-sharingowej. Poza korzyściami dla osób nieposiadających własnego środka transportu car-sharing przyczynia się do redukcji liczby samochodów na drogach i zwiększenia liczby miejsc na zatłoczonych miejskich parkingach. Dodatkowo koszt wynajęcia samochodu jest niszy niż koszty związane z utrzymaniem własnego pojazdu. Głównym czynnikiem wpływającym na redukcję kosztów jest fakt, iż koszty eksploatacji pojazdu ponosi firma oferująca usługę car-sharingową.

Obecnie wyróżnia się trzy rodzaje car-sharingu:

- car-sharing stacjonarny - cechujący się stałymi miejscami poboru i zwrotu pojazdu, bez konieczności zwrotu pojazdu w miejscu jego pobrania,

- car-sharing niestacjonarny lub free-floating - dający możliwość pozostawienia samochodów w dowolnym miejscu (zgodnie z przepisami kodeksu drogowego) na obszarze działalności firmy,

- car-sharing prywatny - oferujący samochód od osób prywatnych (Larish, 2014).

\section{Car-sharing w Europie}

Car-sharing wśród krajów i miast europejskich najwcześniej pojawił się w Niemczech, już w latach 80. Obecnie z roku na roku zyskuje coraz większą popularność. W 2014 r. z usług firm car-sharingowych skorzystało 750 tys. obywateli Niemiec. Usługi takie świadczy ponad 150 firm, w tym znani producenci samochodów, tacy jak BMW, Daimler, Citroen. System free floating jest dostępny w 14 miastach w Niemczech, a system stacjonarnego car-sharingu w 380 miastach i gminach. Firma CiteeCar pobiera należność w wysokości 1-2 euro za godzinę, w zależności od pory dnia².

W Szwecji pierwsza sieć car-sharingu została założona w 1998 roku. Obecnie na terenie Szwecji działa około 30 sieci car-sharingowych. Są to zarówno sieci prywatne, jak i organizacje non profit. W centrach dużych miast deweloperzy

2 http://transinfo.pl/carsharing-w-europie-raport_more_72057.html [dostęp 09.05.2017]. 
decydują się na współpracę z firmami car-sharingowymi w celu redukowania kosztów budowy parkingów. Według szacunków Szwedzkiego Urzędu ds. Ruchu Drogowego, jeden samochód car-sharingowy może zastąpić 5-7 samochodów prywatnych, które są niewykorzystywane przez $90 \%$ czasu33.

Car-sharing w Wielkiej Brytanii jest dostępny w 17 miastach w systemie car-sharingu stacjonarnego, jednak dzięki rozbudowanej sieci parkingów nie stanowi to problemu. Dodatkowo, osoby korzystające z usług są zwolnione z opłat za wjazd do centrum Londynu'.

W Włoszech system cieszy się rosnącą popularnością zwłaszcza w Rzymie i Mediolanie, gdzie osoby korzystające z systemu mają możliwość wjazdu do strefy zamkniętego ruchu w ścisłym centrum i bezpłatnego parkowania. Usługa jest dostępna w 12 miastach na terenie Włoch ${ }^{5}$.

\section{Car-sharing w Polsce}

W Polsce pojawiły się już pierwsze firmy oferujące usługi car-sharingowe. Od 1 października 2016 r. w Krakowie, firma Traficar oferuje usługi w systemie free-floating, a firma 4Mobility w Warszawie oferuje car-sharing w systemie stacjonarnym $^{6}$. We Wrocławiu firma Enigma podpisała umowę o uruchomienie systemu car-sharingu opartego o samochody elektryczne. Start systemu jest zaplanowany na połowę $2018 \mathrm{roku}^{7}$.

\section{Czynniki zewnętrzne i wewnętrzne rozwoju technologii car-sharingu w miastach}

Badania analityczne nad możliwością rozwoju technologii car-sharingu w miastach rozpoczęto od analizy czynników zewnętrznych. Początkowo zidentyfikowano jedynie szczegółowe czynniki środowiska zewnętrznego, a następnie szacowano jego wpływ na rozwój technologii car-sharingu pojazdów jako: pozytywny (wtedy zaliczano czynnik do grupy szans) lub negatywny (wtedy zaliczano czynnik do grupy zagrożeń).

\footnotetext{
3 Tamże.

4 Tamże.

5 Tamże.

6 http://www.warsawsmartcity.pl/traficar-pierwszy-polski-otwarty-carsharing/ [dostęp 09.04.2017].

7 http://polskaparkuje.pl/2017/02/16/ppp-car-sharing-wroclaw/ [dostęp 09.04.2017].
} 
Kolejnym elementem analizy czynników zewnętrznych było przyporządkowanie wag dla poszczególnych kryteriów, tak aby ich suma w każdej grupie szans i zagrożeń była równa 1. Następnie dokonano oceny wpływu każdego czynnika na rozwój technologii car-sharingu w skali 1-5 oraz dokonano przeszacowania na ocenę ważoną. Zestawienie wyników wpływu poszczególnych trzydziestu sześciu czynników przedstawiono w tabeli 1.

Analizując wskaźnikową ocenę ważoną wpływu czynników zewnętrznych na szanse rozwoju technologii car-sharingu, wymienić można trzy najważniejsze: zmniejszenie korków ulicznych $(1,0)$, niski stopień emisji spalin $(0,75)$ oraz niższe koszty jednostkowe $(0,5)$.

Podobnie, biorąc pod uwagę wskaźnikową ocenę ważoną wpływu czynników zewnętrznych na zagrożenia rozwoju technologii car-sharingu, wymienić można najważniejsze: kapitałochłonność technologii $(1,0)$, zmniejszenie popytu na usługi transportowe $(0,5)$ oraz preferowanie prywatnego środka transportu $(0,45)$.

Podobne zestawienie przedstawiono w tabeli 2, w której uwzględniono dwadzieścia trzy czynniki wewnętrzne rozwoju technologii car-sharingu, a następnie w ten sam sposób dokonano ich oceny. Wśród czynników wewnętrznych, zakwalifikowanych do grupy mocnych stron, można wyróżnić dwa najważniejsze: niskie wymiary, większą manewrowość pojazdu $(1,0)$ i możliwość zwrotu pojazdu w wielu miejscach $(0,72)$.

W grupie czynników również można wyróżnić dwa najważniejsze: wyższe koszty utrzymania i wymiany akumulatorów $(0,8)$ oraz konieczność ładowania akumulatorów (0,75). Zestawienie wyników analizy SWOT w postaci graficznego przedstawienia najważniejszych czynników wewnętrznych i zewnętrznych warunkujących rozwój technologii car-sharingu przedstawiono na rysunku 1.

Tabela 1. Analiza wpływu czynników zewnętrznych (szans i zagrożeń) na rozwój technologii car-sharingu

\begin{tabular}{|l|c|c|c|l|l|c|c|}
\hline \multicolumn{4}{|c|}{ SZANSE } & \multicolumn{5}{c|}{ ZAGROŻENIA } \\
\hline \multicolumn{1}{|c|}{ Nazwa czynnika } & Waga & $\begin{array}{c}\text { Ocena } \\
\mathbf{1 - 5}\end{array}$ & $\begin{array}{c}\text { Ocena } \\
\text { ważona }\end{array}$ & Nazwa czynnika & Waga & $\begin{array}{c}\text { Ocena } \\
\mathbf{1 - 5}\end{array}$ & $\begin{array}{c}\text { Ocena } \\
\text { ważona }\end{array}$ \\
\hline $\begin{array}{l}\text { Ochrona intelektual- } \\
\text { na, patentowa }\end{array}$ & 0,01 & 2 & 0,02 & Poziom ubóstwa & 0,06 & 2 & 0,12 \\
\hline Ochrona zdrowia & 0,02 & 2 & 0,04 & Warunki życia & 0,01 & 2 & 0,02 \\
\hline $\begin{array}{l}\text { Postęp technolo- } \\
\text { giczny }\end{array}$ & 0,03 & 2 & 0,06 & $\begin{array}{l}\text { Kapitałochtonność } \\
\text { technologii }\end{array}$ & 0,2 & 5 & 1,00 \\
\hline $\begin{array}{l}\text { Wspieranie wynalaz- } \\
\text { Czości }\end{array}$ & 0,03 & 4 & 0,12 & $\begin{array}{l}\text { Awaryjność w po- } \\
\text { czątkowej fazie }\end{array}$ & 0,05 & 3 & 0,15 \\
\hline $\begin{array}{l}\text { Wysoki stopień } \\
\text { zaawansowania }\end{array}$ & 0,04 & 3 & 0,12 & $\begin{array}{l}\text { Pojawienie się alter- } \\
\text { natywnej technologii }\end{array}$ & 0,05 & 3 & 0,15 \\
\hline
\end{tabular}




\begin{tabular}{|c|c|c|c|c|c|c|c|}
\hline \multicolumn{4}{|c|}{ SZANSE } & \multicolumn{4}{|c|}{ ZAGROŻENIA } \\
\hline Nazwa Czynnika & Waga & $\begin{array}{c}\text { Ocena } \\
1-5\end{array}$ & $\begin{array}{c}\text { Ocena } \\
\text { ważona }\end{array}$ & Nazwa Czynnika & Waga & $\begin{array}{c}\text { Ocena } \\
1-5\end{array}$ & $\begin{array}{c}\text { Ocena } \\
\text { ważona }\end{array}$ \\
\hline $\begin{array}{l}\text { Dostępność } \\
\text { techniczna }\end{array}$ & 0,02 & 3 & 0,06 & $\begin{array}{l}\text { Preferowanie pry- } \\
\text { watnego środka } \\
\text { transportu }\end{array}$ & 0,15 & 3 & 0,45 \\
\hline $\begin{array}{l}\text { Współfinansowanie } \\
\text { projektów }\end{array}$ & 0,03 & 2 & 0,06 & Inflacja & 0,05 & 3 & 0,15 \\
\hline Wzrost PKB & 0,02 & 3 & 0,06 & Zmiany kursów walut & 0,05 & 3 & 0,15 \\
\hline $\begin{array}{l}\text { Większa przepusto- } \\
\text { wość na drogach }\end{array}$ & 0,04 & 4 & 0,16 & $\begin{array}{l}\text { Konieczność recy- } \\
\text { klingu nowych po- } \\
\text { jazdów }\end{array}$ & 0,13 & 3 & 0,39 \\
\hline Wysokość podatków & 0,02 & 2 & 0,04 & $\begin{array}{l}\text { Odpady produk- } \\
\text { cyjne }\end{array}$ & 0,05 & 2 & 0,10 \\
\hline $\begin{array}{l}\text { Zmniejszenie korków } \\
\text { ulicznych }\end{array}$ & 0,25 & 4 & 1 & $\begin{array}{l}\text { Świadczenia pu- } \\
\text { bliczne w zakresie } \\
\text { transportu dla } \\
\text { mieszkańców }\end{array}$ & 0,02 & 5 & 0,10 \\
\hline $\begin{array}{l}\text { Niski stopień emisji } \\
\text { spalin }\end{array}$ & 0,15 & 5 & 0,75 & $\begin{array}{l}\text { Niestabilność poli- } \\
\text { tyczna }\end{array}$ & 0,01 & 2 & 0,02 \\
\hline $\begin{array}{l}\text { Alternatywne źródło } \\
\text { energii }\end{array}$ & 0,05 & 4 & 0,2 & $\begin{array}{l}\text { Działalność ruchów } \\
\text { populistycznych, } \\
\text { ruchów miejskich }\end{array}$ & 0,02 & 5 & 0,10 \\
\hline $\begin{array}{l}\text { Wsparcie państwa } \\
\text { dla rozwoju tech- } \\
\text { nologii }\end{array}$ & 0,05 & 3 & 0,15 & Rozwój biurokracji & 0,02 & 3 & 0,06 \\
\hline Przynależność do UE & 0,03 & 2 & 0,06 & $\begin{array}{l}\text { Zmniejszenie popy- } \\
\text { tu na usługi trans- } \\
\text { portowe }\end{array}$ & 0,1 & 5 & 0,50 \\
\hline $\begin{array}{l}\text { System demokra- } \\
\text { tyczny, wielopartyjny }\end{array}$ & 0,04 & 2 & 0,08 & Rozwój biurokracji & 0,02 & 3 & 0,06 \\
\hline $\begin{array}{l}\text { Zachęcanie imigran- } \\
\text { tów do powrotu, } \\
\text { programy repatria- } \\
\text { cyjne }\end{array}$ & 0,02 & 3 & 0,06 & $\begin{array}{l}\text { Odpowiedzialność } \\
\text { prawna w przypad- } \\
\text { ku bezprawnego } \\
\text { przejęcia pojazdu }\end{array}$ & 0,01 & 5 & 0,05 \\
\hline $\begin{array}{l}\text { Wygodny sposób } \\
\text { wypożyczania samo- } \\
\text { chodu }\end{array}$ & 0,05 & 4 & 0,2 & & & & \\
\hline $\begin{array}{l}\text { Niższe koszty jed- } \\
\text { nostkowe }\end{array}$ & 0,1 & 5 & 0,5 & & & & \\
\hline Suma & 1 & & & Suma & 1 & & \\
\hline
\end{tabular}

Źródło: opracowanie własne. 
Tabela 2. Analiza wpływu czynników wewnętrznych (mocnych i słabych stron) na rozwój technologii car-sharingu

\begin{tabular}{|c|c|c|c|c|c|c|c|}
\hline \multicolumn{4}{|c|}{ MOCNE STRONY } & \multicolumn{4}{|c|}{ SŁABE STRONY } \\
\hline Nazwa czynnika & Waga & $\begin{array}{c}\text { Ocena } \\
1-5\end{array}$ & $\begin{array}{c}\text { Ocena } \\
\text { ważona }\end{array}$ & Nazwa czynnika & Waga & $\begin{array}{c}\text { Ocena } \\
1-5\end{array}$ & $\begin{array}{c}\text { Ocena } \\
\text { ważona }\end{array}$ \\
\hline $\begin{array}{l}\text { Możliwość zwrotu } \\
\text { pojazdu w wielu } \\
\text { miejscach }\end{array}$ & 0,18 & 4 & 0,72 & Wysokie inwestycje & 0,06 & 4 & 0,24 \\
\hline $\begin{array}{l}\text { Prostota wypożycze- } \\
\text { nia pojazdu }\end{array}$ & 0,05 & 3 & 0,15 & $\begin{array}{l}\text { Cykle życia produk- } \\
\text { tu, technologii }\end{array}$ & 0,04 & 4 & 0,16 \\
\hline $\begin{array}{l}\text { Niższy koszt wyna- } \\
\text { jęcia samochodu } \\
\text { w porównaniu } \\
\text { z kosztem utrzyma- } \\
\text { nia prywatnego }\end{array}$ & 0,05 & 5 & 0,25 & $\begin{array}{l}\text { Preferowanie wła- } \\
\text { snego środka trans- } \\
\text { portu }\end{array}$ & 0,05 & 2 & 0,10 \\
\hline $\begin{array}{l}\text { Zmniejszone spala- } \\
\text { nie paliwa }\end{array}$ & 0,04 & 5 & 0,20 & $\begin{array}{l}\text { Konieczność łado- } \\
\text { wania pojazdu }\end{array}$ & 0,25 & 3 & 0,75 \\
\hline $\begin{array}{l}\text { Zmniejszona emisja } \\
\text { zanieczyszczeń }\end{array}$ & 0,05 & 4 & 0,20 & $\begin{array}{l}\text { Wysoki koszt napraw } \\
\text { i przeglądów }\end{array}$ & 0,05 & 4 & 0,20 \\
\hline $\begin{array}{l}\text { Zmniejszony poziom } \\
\text { hałasu }\end{array}$ & 0,05 & 4 & 0,20 & $\begin{array}{l}\text { Brak odpowiedniej } \\
\text { infrastruktury }\end{array}$ & 0,04 & 4 & 0,16 \\
\hline $\begin{array}{l}\text { Klient nie opłaca } \\
\text { kosztów eksploatacji }\end{array}$ & 0,15 & 3 & 0,45 & $\begin{array}{l}\text { Mała pojemność } \\
\text { bagażnika }\end{array}$ & 0,05 & 1 & 0,05 \\
\hline $\begin{array}{l}\text { Bezobsługowy od- } \\
\text { biór samochodu }\end{array}$ & 0,04 & 4 & 0,16 & $\begin{array}{l}\text { Maksymalna pręd- } \\
\text { kość } 80 \mathrm{~km} / \mathrm{h}\end{array}$ & 0,05 & 4 & 0,2 \\
\hline $\begin{array}{l}\text { Ulgi dla kierowców } \\
\text { korzystających z car- } \\
\text {-sharingu }\end{array}$ & 0,04 & 3 & 0,12 & $\begin{array}{l}\text { Ograniczony zasięg } \\
\text { jazdy }\end{array}$ & 0,15 & 2 & 0,30 \\
\hline $\begin{array}{l}\text { Ładowanie pojazdu } \\
\text { w domowych gniaz- } \\
\text { dach }\end{array}$ & 0,05 & 2 & 0,10 & $\begin{array}{l}\text { Wyższe koszty utrzy- } \\
\text { mania i wymiany } \\
\text { akumulatorów }\end{array}$ & 0,20 & 4 & 0,80 \\
\hline $\begin{array}{l}\text { Niskie wymiary, } \\
\text { większa manewro- } \\
\text { wość pojazdu }\end{array}$ & 0,25 & 4 & 1,00 & $\begin{array}{l}\text { Koszt eksploatacji } \\
\text { pokrywa firma car- } \\
\text {-sharingowa }\end{array}$ & 0,06 & 4 & 0,24 \\
\hline $\begin{array}{l}\text { Rezerwacja pojazdu } \\
\text { przez Internet }\end{array}$ & 0,05 & 4 & 0,20 & & & & \\
\hline Suma & 1 & & & Suma & 1 & & \\
\hline
\end{tabular}

Źródło: opracowanie własne. 


\begin{tabular}{|c|c|c|}
\hline 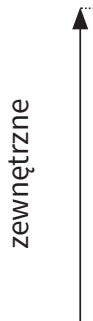 & $\begin{array}{l}\text { O (Szanse) } \\
\text { - zmniejszenie korków ulicznych }(1,0) \\
\text { - niski stopień emisji spalin }(0,75) \\
\text { - niższe koszty jednostkowe }(0,5)\end{array}$ & $\begin{array}{l}\text { T (Zagrożenia) } \\
\text { - } \text { kapitałochłonność technologii }(1,0) \\
\text { portowe }(0,5) \\
\text { - preferowanie prywatnego środka } \\
\text { transportu }(0,45)\end{array}$ \\
\hline$\frac{\stackrel{Q}{N}}{\stackrel{N}{ \pm}}$ & $\begin{array}{l}\text { S (Mocne strony) } \\
\text { - niskie wymiary, większa manewro- } \\
\text { wość pojazdu }(1,0) \\
\text { - możliwość zwrotu pojazdu w wielu } \\
\text { miejscach }(0,72)\end{array}$ & $\begin{array}{l}\text { W (Stabe strony) } \\
\text { - wyższe koszty utrzymania i wymiany } \\
\text { akumulatorów }(0,8) \\
\text { - konieczność ładowania akumulato- } \\
\text { rów }(0,75)\end{array}$ \\
\hline IKI & pozytywne & wne \\
\hline
\end{tabular}

Rysunek 1. Klasyfikacja kluczowych czynników wpływających na rozwój technologii car-sharingu w analizie SWOT

Źródto: opracowanie własne.

\section{Podsumowanie}

Obecne tendencje w organizacji transportu miejskiego to dążenie do wprowadzenia coraz bardziej efektywnych i proekologicznych rozwiązań w transporcie, co wynika $\mathrm{z}$ dostrzegania negatywnych skutków transportu drogowego, tj. emitowania smogu, hałasu, pyłów.

Ciągle rozwijające się miasta generują potrzebę rozbudowy infrastruktury. Dąży się do zmniejszenia natężenia ruchu na drogach, zmniejszenia potoków ruchu między innymi przez komunikację publiczną czy takie projekty jak car-sharing.

Należy przypuszczać, że pojazdy elektryczne zdobędą w przyszłości popularność i w konsekwencji wyprą pojazdy z napędami silnikowymi. Dodatkowo możliwości, jakie oferuje car-sharing, tj. wypożyczanie jedno- dwuosobowych samochodów, prostota w zamawianiu i w zwrocie, niższe ceny, są doskonałą alternatywą dla kierowców poruszających się po miastach. W przyszłości technologie zostaną ulepszone, co będzie skutkować jeszcze lepszymi wynikami.

W części badawczej niniejszego artykułu przeprowadzona została analiza złożoności problemu wprowadzenia nowoczesnej technologii w logistyce miejskiej przy użyciu analizy SWOT. W tym celu wygenerowano trzydzieści sześć czynników zewnętrznych, które poddano analizie. Ocena pozwoliła wybrać po trzy kluczowe czynniki zewnętrzne mające wpływ na szanse i zagrożenia związane z rozwojem 
technologii car-sharingu. Ocena pozwoliła wybrać sześć kluczowych czynników zewnętrznych mających wpływ na szanse i zagrożenia związane z rozwojem car-sharingu, do których zaliczono w grupie szans: zmniejszenie korków ulicznych $(1,0)$, niski stopień emisji spalin $(0,75)$ oraz niższe koszty jednostkowe $(0,5)$, natomiast w grupie zagrożeń: kapitałochłonność technologii $(1,0)$, zmniejszenie popytu na usługi transportowe $(0,5)$ i preferowanie prywatnego środka transportu $(0,45)$.

Jednocześnie uwzględniono dwadzieścia trzy czynniki wewnętrzne rozwoju technologii car-sharingu, a następnie w ten sam sposób dokonano ich oceny i wyboru czterech najważniejszych: niskie wymiary, większa manewrowość pojazdu $(1,0)$, możliwość zwrotu pojazdu w wielu miejscach $(0,72)$ oraz wyższe koszty utrzymania i wymiany akumulatorów $(0,8)$ i konieczność ładowania akumulatorów $(0,75)$.

Podsumowując, można stwierdzić, że koncerny motoryzacyjne i elektroniczne traktują pojazdy z napędem elektrycznym jako naturalny kierunek rozwoju transportu drogowego. Dodatkowo technologie takie jak car-sharing umożliwiają zmniejszenie liczby pojazdów osobowych na drogach, co skutkuje lepszą organizacją transportu i infrastruktury oraz sprzyja ekologii.

W związku z tym należy maksymalnie wykorzystać mocne strony i szanse, a zarazem zniwelować słabe strony i zagrożenia wynikające $\mathrm{z}$ tej technologii także dla rozwoju transportu miejskiego.

\section{Bibliografia}

Chłopek Z., (2012), Badanie zużycia energii przez samochód elektryczny, Instytut Transportu Samochodowego, Warszawa.

Chłopek Z., Lasocki J., (2014), Badania zużycia energii przez samochód elektryczny w warunkach ruchu w mieście, „Zeszyty Naukowe Instytutu Pojazdów”, nr 1 (97), s. 33-39.

Janasz M., Kałużyński P., (2016), Logistyka miejska w dobie wyzwań transportowych, Wyzwania wspótczesnej logistyki, Uniwersytet Łódzki, Łódź.

Larish R., (2014), Car Sharing. Biblioteka Źródtowa Energetyki Prosumenckiej, http://ilabepro. polsl.pl/bzep/static/uploads/LARISCH_Romuald_-_Car_Sharing.pdf [dostęp 05.04.2017].

Pawelski Z., Pawelski W., Pałczyński T., (2007), Wybrane prototypowe istudialne pojazdy hybrydowo-elektryczne, „Zeszyty Problemowe - Maszyny Elektryczne”, nr 76, s. 19-24.

\section{Źródta internetowe}

http://moto.pl/MotoPL/1,88389,14055475,Renault_Twizy_w_Polsce_Ceny_od_33_900_ zl.html [dostęp 06.04.2017].

http://polskaparkuje.pl/2017/02/16/ppp-car-sharing-wroclaw/ [dostęp 09.04.2017]. http://transinfo.pl/carsharing-w-europie-raport_more_72057.html [dostęp 09.05.2017].

http://www.warsawsmartcity.pl/traficar-pierwszy-polski-otwarty-carsharing/[dostęp09.04.2017]. 